\title{
Gender Differences in Entrepreneurial Skills' Acquisition: An Analysis of Informal Institutional Factors
}

\author{
${ }^{1}$ Ismail Olaniyi, Muraina; ${ }^{2}$ Soladoye Nurudeen Lameed; ${ }^{3}$ Bernice Olufunmilola, \\ Lesi ${ }^{4}$ Oloyede Solomon, Aregbede \& ${ }^{5}$ Olawale Adejumo Osunloye \\ ${ }^{1 \& 3}$ School of Science (SOS) Computer Science Department Adeniran Ogunsanya College of Education \\ Otto/Ijanikin, Lagos. P.M.B 007, Festac Town, Lagos Nigeria \\ ${ }^{2}$ Centre for Sandwich Degree Programme (CESADEP) Adeniran Ogunsanya College of Education \\ Otto/Ijanikin, Lagos. P.M.B 007, Festac Town, Lagos Nigeria \\ ${ }^{4}$ School of Part-Time Studies (SPS) Adeniran Ogunsanya College of Education Otto/Ijanikin, Lagos. P.M.B 007, \\ Festac Town, Lagos Nigeria \\ ${ }^{5}$ School of Science (SOS) Integrated Science Department Adeniran Ogunsanya College of Education \\ Otto/Ijanikin, Lagos. P.M.B 007, Festac Town, Lagos Nigeria
}

\begin{abstract}
The study looks into gender differences in entrepreneurial skills acquisition. 110 entrepreneurial students formed the sample of this study across two institutions in Lagos State using survey design method. Data were collected through the use of questionnaire. Three hypotheses were formulated and tested using inferential statistics (Chi-Square). The findings show that parental education, socio-economic status and religious influence have significant impact on entrepreneurial skills attainment of the children. The findings also reveal that marketing related value with regards to choice of entrepreneurial skills has nothing to do with being a male or female.
\end{abstract}

\section{Introduction}

Women's entrepreneurship has been recognized during the last decade as an important untapped source of economic growth (OECD, 2004). Women entrepreneur creates new jobs for themselves and others and by being different, also provide society with different solutions to management, organization and business problems as well as to the exploitation of entrepreneurial opportunities. However, women in entrepreneurship have been largely neglected in the society and in most especially social sciences (Brush \& Hisrich, 1999; Holmquist \& Sundin, 2002). Not that women have lower participation rate in entrepreneurship than men, but they generally choose to start and manage firms in different industries than men tend to do (Duchenaut, 1997).

Furthermore, many researches, policies and programmes tend to be "men streamed" and often do not take into account the specific needs of women entrepreneurs Correll, (2001). As a result of this, equal opportunity between men and women from the perspective of entrepreneurship is still not a reality. This paper examines informal institutional factors that propel gender differences in entrepreneurial activity such as parental education, socio-economic status, religious influence and marketing related value

\section{Gender and Entrepreneurship}

Many researches carried out in the domain of women's entrepreneurship have not come as a response from the research community as a poorly understood and theoretically interesting phenomenon. Rather, the research that has been conducted on women's entrepreneurship comes as a reaction from different policy institutes (such as government agencies, European union, Organization for Economic Co-operation and Development -OECD) needing better information in order to initiate measures to support women's entrepreneurship coupled with the intrinsic motivation emanating from individual women researchers in the field. Both researchers and different policy institutes have now started to recognize that the gender system as anywhere else in society plays also an important role in shaping entrepreneurship and economic growth.

\section{Demand and Supply Side of Entrepreneurship}

This entrepreneurship literature as well as the literature on sex segregations can be classified into two schools (OECD,2004). The first one examines the demand-side process while the other one examines the supply-side processes (Correll, 2001; Thornton, 1999).

The demand-side school focuses on the number and nature of the entrepreneurial roles that can be filled. That is, the processes such as statistical discrimination, internal labour markets and the gendering of jobs that affect the land of entrepreneurial opportunities which are offered to women in comparison to men. Specifically, the demand-side can be viewed from three major conditions to gender inequality; political and institutional framework, family policy and market sources (Van der Lippe \& Van Dijk, 2002). 
The supply-side school focuses on the availability of suitable individuals to occupy entrepreneurial roles. This is the reason why men and women move differently into various activities associated with entrepreneurship. Take for instance, women entrepreneurs tend to exploit opportunities in some specific industries like education and health care rather than manufacturing. Behaviour is assumed to be intentional, but is limited by the demands mode by society (Aldrich, 1979, 1999).The supply-side can be attributed to human capital (Becker, 1964), norms (Dimaggio,1997) and family-related factors (Lin,1999;Loscocco \& Leicht,1993).

\section{Demand side of entrepreneurship}

Political and institutional framework conditions like occupational closure and occupational segregation drive women's entrepreneurship simply because both suppress women's ability to discover all entrepreneurial opportunities as many may correlate with a particular occupation. Occupational closure according to (Cahill, 2001, Davies, 1996 and Witz, 1990) is dejure or de facto exclusion of specific groups of people from particular lines of work. For instance, women were for a long time not allowed to participate in the armed forces or it was not until 1983 that all professions' were opened to women according to the law in Sweden and in France to mention but two countries (OECD, 2004). In many developing countries like Nigeria, strong legal prohibitions still prevail on women entering particular profession occupations. This is very common in many countries especially when religious doctrines are incorporated in the system.

This can be traced to many countries in Africa and in Asia. According to Mork-Turner (2011) business groups in South Korean, due to government ties and monopoly powers, exercise substantial influence on their labour markets by persistent patterns of gender-discrimination in employment practices. Rhein (1998) also reports widespread gender-based employment discrimination in both the government and private sectors in Russia and argues that lack of political will to combat these problems has made the situation worse. In consonance with these arguments, some analysts suggest that discrimination in labour markets(in emerging economies) creates disincentives for investment in developing female talent (kingdom ,1998), as the human capital produced is improbable to ever be fully utilized. Occupation segregation accounts for most of the gender gap in earnings at the macro level, but contextual association decreases the relative earnings of all women, no just women employed in female-dominated occupations (Cotter, DeFiore, Hermsen \& Mars teller, 1997). This conclusively means that all women are better off working in a gender-disaggregate labour market, all other things being equal. Also occupations are highly skewed in all countries when examined at the level of the organization .Women are much less probable to be promoted than their male counterparts in almost any organization examined (Smith, 2002).

\section{Supply side of entrepreneurship}

It is important to understand that the gendering of the labour market and entrepreneurship has its source in the way in which men and women move into various activities associated with different kinds of work. Corell (2001) shows how gender differences in the perception of specific competence such as entrepreneurial competence or mathematical competence, influence young women's educational decisions.

In most economically developed countries the process by which young men and women move differently into activities relevant to careers in engineering and the physical sciences is not dependent on class as men and women tend to be equally distributed across social classes and attend the same schools. Gender has to be seen as a multilevel system in order to understand voluntary choices of careers. Gender is a multilevel system that consists not only of roles and identities, but also includes ways of behaving in relation to one another at this interactional level and cultural beliefs and distribution of resources at the macro level (Ridgeway, 1997; Risman, 1998). Many studies have shown that people in general view entrepreneurship as masculine and perceive entrepreneurship to be a male domain (Dimaggio,1997, Holmquist et. al,2002). Research on gender beliefs also shows that a collective (such as small business men) struggles to self-name, self-characterize and claim prerogative. Such concerns underscore the politics of identity (Cerulo, 1997). From that perspective, it seems logical that women cannot or will not identify with the group of self-employed and the group is perhaps not interested in women joining them. Also both the work task and the work description related to entrepreneurship such as leadership, high commitment risk taking, performance and achievement orientation independence, flexibility, sense of adventure and aggressiveness do no define entrepreneurship as a task that can be seen as "feminine".

Having critically examined the supply and demand side of entrepreneurship, researches have clearly showed that some factors affect the choice of both male and female towards entrepreneurial skills. These factors according to Nnaka and Ezekannagha (2009) include socio-cultural, education finance, market and use of old technologies. 
Hypotheses

The following hypotheses are formulated for the study:

$\checkmark$ There is no statistically significant relationship between parental education factor and gender entrepreneurial skills.

$\checkmark$ Social economic status will have no significant relationship with gender choice of entrepreneurial skills development.

$\checkmark$ There is no statistically significant influence of religion groups on entrepreneurial skills.

$\checkmark$ Marketing related value has no significant relationship with gender choice of entrepreneurial skills.

\section{Instrumentation}

\section{Methodology}

Questionnaire form the major instrument used to generate data in this study. The questionnaire items were structured to measure parental education level, socio-economic status, religion and market related value. The instrument consists of two sections A and B: Section A measures bio-data of the respondents; while section B comprises twenty items eliciting response from the subjects on the main variable considered in the study using four-point Likert scale (SA- Strongly Agree, A- Agree, D- Disagree, SD- Strongly Disagree)

\section{Subjects and Data Collected}

Data were collected from a sample of 110 entrepreneurship students enrolled in four different programmes, all situated in Lagos State Tertiary Institutions.

1. Group 1: 28 Regular degree students undergoing a three month course in entrepreneurship education at Adeniran Ogunsanya College of Education.

2. Group 2: 28 sandwich degree students undergoing a two month course in entrepreneurship education at Adeniran Ogunsanya College of Education.

3. Group 3: 27 Regular N.C.E students undergoing a three month course in entrepreneurship education at Adeniran Ogunsanya College of Education.

4. Group 4: 27 engineering and technical students undergoing one year programme in entrepreneurship education at Yaba College of Technology.

The data were collected through a survey in the form of self-administered questionnaire. The questionnaires were distributed to the students at their school' locations, and filled out with one of the researchers present in order to answer questions. The researchers were careful to tell all students that there were no "right", or "wrong", answers and that they would not be evaluated as individuals in any way. Two students out of group 1, five students in group 2, and three in group 4 were unable to complete the questionnaire which gave a total of 100 retrieved questionnaires that serve the basis of the data used for the study.

Since all these stated reasonable grounds for not participating (e.g sickness, out of schools for some weeks, having appointment somewhere), we can think of no reason why they would be particularly different on variables than the rest of the groups, although we have no way of measuring whether this is indeed the case or not. The study is based upon the assumption that we have a non-biased sample of entrepreneurship in the relevant programmes. The respondent's average age was 18 years and 50 percent were males and 50 per cent females.

\section{Validity and Reliability}

The content validity of the instrument was determined by experts in tests and measurement who matched each item of the questionnaire with the research hypotheses to ascertain whether the instrument actually measured what it was supposed to measure. Also, the reliability of the instrument was determined through test-retest technique. In doing this, the instruments were administered to 20 respondents different from the sample respondents, the same subjects were retested within the period of two weeks interval. Hence, the data collected were collated and analyzed using the Pearson Product Moment (PPM) reliability. A correlation coefficient " $r$ " of 0.89 was obtained indicating that the instrument was reliable for the study.

\section{Statistical Analysis}

Our hypotheses were investigated through chi-square. Before analyzing the data, the researchers verified that the variables in gender difference towards entrepreneurial skills were cross-tabulated to ensure that no cell has an expected value of less than one and not more than 25 per cent of the cells should have expected values less than five. In order to find out the measures of strength of relationship, the effect size for chi-square test was conducted (phi) by taking the square root of the calculated value of chi-square divided by the overall sample size. The effect size measure varies between 0 (no relationship) and 1 (perfect positive relationship). We have no reason to suspect weak relationship despite its being significant. 
Gender Differences in Entrepreneurial Skills' Acquisition: An Analysis of Informal Institutional V. Testing of Hypotheses

$\mathbf{H}_{\mathbf{0}}$ 1: There is no statistically significant relationship between parental education factor and gender entrepreneurial skills.

\begin{tabular}{|c|c|c|c|c|c|c|c|}
\hline & & & \multicolumn{4}{|c|}{ Parental education entrepreneurial skills } & \multirow[b]{2}{*}{ Total } \\
\hline & & & $\begin{array}{l}\text { Strongly } \\
\text { Disagree }\end{array}$ & Disagree & Agree & $\begin{array}{l}\text { Strongly } \\
\text { Agree }\end{array}$ & \\
\hline \multirow[t]{4}{*}{ Gender } & Male & Count & 12 & 15 & 10 & 6 & 43 \\
\hline & & Expected Count & 8.6 & 16.8 & 14.2 & 3.4 & 43.0 \\
\hline & Female & Count & 8 & 24 & 23 & 2 & 57 \\
\hline & & Expected Count & 11.4 & 22.2 & 18.8 & 4.6 & 57.0 \\
\hline \multirow[t]{2}{*}{ Total } & & Count & 20 & 39 & 33 & 8 & 100 \\
\hline & & Expected Count & 20.0 & 39.0 & 33.0 & 8.0 & 100.0 \\
\hline
\end{tabular}

Table 2: Chi-Square Tests

\begin{tabular}{lccr}
\hline & Value & df & $\begin{array}{c}\text { Asymp. Sig. } \\
\text { (2-sided) }\end{array}$ \\
\hline Pearson Chi-Square & $8.199^{\mathrm{a}}$ & 3 & .042 \\
Likelihood Ratio & 8.290 & 3 & .040 \\
Linear-by-Linear & .322 & 1 & .571 \\
Association & 100 & & \\
N of Valid Cases & & & \\
\hline
\end{tabular}

a. 2 cells $(25.0 \%)$ have expected count less than 5 . The minimum expected count is 3.44 .

\section{Table 3: Symmetric Measures}

\begin{tabular}{llrr}
\hline & & Value & Approx. Sig. \\
\hline Nominal by & Phi & .286 & .042 \\
Nominal & Cramer's V & .286 & .042 \\
N of Valid Cases & & 100 & \\
\hline
\end{tabular}
a. Not assuming the null hypothesis.
b. Using the asymptotic standard error assuming the null hypothesis.

A Chi-Square Test was conducted to find the significant relationship between parental education factor and gender entrepreneurial skills. A significant effect was found [Chi-Square $=8.199, d f=3, p=.042$ ]. The magnitude of the effect was found weak (Phi=0.286).

$\mathbf{H}_{\mathbf{0}}$ 2: Social economic status will have no significant relationship with gender choice of entrepreneurial skills development.

Table 4: Gender * Socio economic status entrepreneurial skills Cross-tabulation

\begin{tabular}{|c|c|c|c|c|c|c|c|}
\hline & & & \multicolumn{4}{|c|}{ Socio economic status entrepreneurial skills } & \multirow[b]{2}{*}{ Total } \\
\hline & & & $\begin{array}{l}\text { Strongly } \\
\text { Disagree }\end{array}$ & Disagree & Agree & $\begin{array}{l}\text { Strongly } \\
\text { Agree }\end{array}$ & \\
\hline \multirow[t]{4}{*}{ Gender } & Male & Count & 7 & 20 & 16 & 0 & 43 \\
\hline & & Expected Count & 14.6 & 17.2 & 10.8 & .4 & 43.0 \\
\hline & Female & Count & 27 & 20 & 9 & 1 & 57 \\
\hline & & Expected Count & 19.4 & 22.8 & 14.3 & .6 & 57.0 \\
\hline \multirow[t]{2}{*}{ Total } & & Count & 34 & 40 & 25 & 1 & 100 \\
\hline & & Expected Count & 34.0 & 40.0 & 25.0 & 1.0 & 100.0 \\
\hline
\end{tabular}


Table 5: Chi-Square Tests

\begin{tabular}{lccr}
\hline & Value & df & $\begin{array}{c}\text { Asymp. Sig. } \\
\text { (2-sided) }\end{array}$ \\
\hline Pearson Chi-Square & $13.020^{\mathrm{a}}$ & 3 & .005 \\
Likelihood Ratio & 13.966 & 3 & .003 \\
$\begin{array}{l}\text { Linear-by-Linear } \\
\text { Association }\end{array}$ & 9.320 & 1 & .002 \\
N of Valid Cases & 100 & & \\
\hline \multicolumn{1}{l}{ a. 2 cells (25.0\%) have expected count less than 5. The } \\
$\quad$ minimum expected count is .43.
\end{tabular}

Table 6: Symmetric Measures

\begin{tabular}{llrr}
\hline & & Value & Approx. Sig. \\
\hline Nominal by & Phi & .361 & .005 \\
Nominal & Cramer's V & .361 & .005 \\
N of Valid Cases & & 100 & \\
\hline
\end{tabular}

a. Not assuming the null hypothesis.

b. Using the asymptotic standard error assuming the null hypothesis.

A Chi-Square Test was conducted to find the significant relationship between socio-economic status and entrepreneurial skills development. A significant effect was observed [Chi-Square $=13.020, d f=3, p=.005$ ]. The magnitude of the effect was modest (Phi=0.361).

$\mathbf{H}_{\mathbf{0}}$ 3: There is no statistically significant influence of religion groups on entrepreneurial skills.

Table 7: Religion * Entrepreneurial skills' development Cross-tabulation

\begin{tabular}{|c|c|c|c|c|c|c|c|}
\hline & & & \multicolumn{4}{|c|}{ Entrepreneurial skills' development } & \multirow[b]{2}{*}{ Total } \\
\hline & & & $\begin{array}{l}\text { Strongly } \\
\text { Disagree }\end{array}$ & Disagree & Agree & $\begin{array}{l}\text { Strongly } \\
\text { Agree }\end{array}$ & \\
\hline \multirow[t]{6}{*}{ Religion } & Christianity & Count & 24 & 16 & 3 & 1 & 44 \\
\hline & & Expected Count & 14.5 & 15.4 & 11.0 & 3.1 & 44.0 \\
\hline & Islam & Count & 6 & 14 & 12 & 1 & 33 \\
\hline & & Expected Count & 10.9 & 11.6 & 8.3 & 2.3 & 33.0 \\
\hline & Tradition & Count & 3 & 5 & 10 & 5 & 23 \\
\hline & & Expected Count & 7.6 & 8.1 & 5.8 & 1.6 & 23.0 \\
\hline \multirow[t]{2}{*}{ Total } & & Count & 33 & 35 & 25 & 7 & 100 \\
\hline & & Expected Count & 33.0 & 35.0 & 25.0 & 7.0 & 100.0 \\
\hline
\end{tabular}

Table 8: Chi-Square Tests

\begin{tabular}{lccr}
\hline & Value & df & $\begin{array}{c}\text { Asymp. Sig. } \\
\text { (2-sided) }\end{array}$ \\
\hline Pearson Chi-Square & $32.809^{\mathrm{a}}$ & 6 & .000 \\
Likelihood Ratio & 32.918 & 6 & .000 \\
$\begin{array}{l}\text { Linear-by-Linear } \\
\text { Association }\end{array}$ & 25.641 & 1 & .000 \\
N of Valid Cases & 100 & & \\
\hline \multicolumn{1}{l}{ a. 3 cells (25.0\%) have expected count less than 5. The } \\
$\quad$ minimum expected count is 1.61.
\end{tabular}


Table 9: Symmetric Measures

\begin{tabular}{llrr}
\hline & & Value & Approx Sig. \\
\hline Nominal by & Phi & 573 & .000 \\
Nominal & Cramer's V & 405 & .000 \\
N of Valid Cases & & 100 & \\
\hline \multicolumn{2}{l}{ a. Not assuming the null hypothesis } \\
b. Using the asymptotic standard error assuming the null \\
Hypothesis
\end{tabular}

A Chi-Square Test was conducted to find the significant influence of religion groups on entrepreneurial skills. A significant effect was found [Chi-Square $=32.809, d f=6, p=.0001]$. The magnitude of the effect was found moderate $(P h i=0.573)$.

$\mathbf{H}_{\mathbf{0}}$ 4: Marketing related value has no significant relationship with gender choice of entrepreneurial skills.

\begin{tabular}{|c|c|c|c|c|c|c|c|}
\hline & & & \multicolumn{4}{|c|}{ Marketing value of entrepreneurial skills } & \multirow[b]{2}{*}{ Total } \\
\hline & & & $\begin{array}{l}\text { Strongly } \\
\text { Disagree }\end{array}$ & Disagree & Agree & $\begin{array}{l}\text { Strongly } \\
\text { Agree }\end{array}$ & \\
\hline \multirow[t]{4}{*}{$\overline{\text { Gender }}$} & Male & Count & 0 & 16 & 15 & 12 & 43 \\
\hline & & Expected Count & 1.3 & 14.6 & 16.3 & 10.8 & 43.0 \\
\hline & Female & Count & 3 & 18 & 23 & 13 & 57 \\
\hline & & Expected Count & 1.7 & 19.4 & 21.7 & 14.3 & 57.0 \\
\hline \multirow[t]{2}{*}{ Total } & & Count & 3 & 34 & 38 & 25 & 100 \\
\hline & & Expected Count & 3.0 & 34.0 & 38.0 & 25.0 & 100.0 \\
\hline
\end{tabular}

Table 11: Chi-Square Tests

\begin{tabular}{lccc}
\hline & Value & dt & $\begin{array}{c}\text { Asymp Sig } \\
\text { (2-sided; }\end{array}$ \\
\hline Pearson Chi-Square & $2.939^{2}$ & 3 & .401 \\
Likelihood Ratio & 4.047 & 3 & .256 \\
Linear-by-Linear & .353 & 1 & .553 \\
Association & 100 & & \\
N of Valid Cases & \multicolumn{1}{l}{ a. 2 cells (25.0\%) have expected count less than 5. The } \\
$\quad$ Minimum expected ceunt is 1.29.
\end{tabular}

Tale 12: Symmetric Measures

\begin{tabular}{llrr}
\hline & & Value & Approx Sig. \\
\hline Nominal by & Phi & 171 & .401 \\
Nominal & Cramer's V & 171 & .401 \\
N of Valid Cases & 100 & \\
\hline \multicolumn{2}{l}{ a. Not assuming the null hypothesis } & & \\
b. Using the asymptotic standard error assuming the null \\
\multicolumn{2}{l}{ hypothesis. }
\end{tabular}

A Chi-Square Test was conducted to find the Marketing related value on significant relationship between gender and choice of entrepreneurial skills. A non significant effect was found [Chi-Square $=2.939, d f$ $=3, p=.401]$. The magnitude of the effect was found very weak $(P h i=0.171)$.

\section{Discussion of Findings}

The findings of the study show that the education of the parent and socio economic status have significant relation with the choice of entrepreneur of the male and female students in the institution of higher learning. This is in agreement with assertion of Nnaka and Ezekannagha (2009) who opined that socio economic status and education are vital factors considered by men and women in choosing entrepreneur. The evidence suggests that students of well educated background and high socio economics status are better to go for entrepreneurial skills that are financially demand than their counterparts from parent of low education and socio economic status (see table 1-6). Davidsson (1991) supported this view by saying that the beliefs of relevant groups and actors, such as family, friends, colleagues and customers, affect the intention of the entrepreneur.

The study further shows that religion has significant relationship with male and female choice of entrepreneurial skills. This implies that both male and female consider their religion inclination when making a career choice, in some cases their religious leaders choose their career for them (see table 7-9).

Table 10-12 reveals that being a male or female has nothing to do with valuing a specific type of entrepreneurial skills. This view is in contrary to the findings of Driga, Lafuente and Vaillant (2009) that establish the 
importance of entrepreneurial self-confidence as a common factor for both women and men towards entrepreneurial activities against their gender differences.

\section{Conclusion}

There is a continuing interest in the field of entrepreneurship education and entrepreneurial skill development and research in this area has grown rapidly over the years. Despite the growth in entrepreneurship education and training, there is little discourse on gender issues on entrepreneurial skills development. Nonetheless, some factors like political and institutional framework, family policy and market sources are demand driven while entrepreneurial competence and self- confidence are supply driven factors. Empirical evidence indicates that parental education, socio-economic status and religious influence have significant impact on entrepreneurial skills attainment of the children. The findings also reveal that marketing related value with regards to choice of entrepreneurial skills has nothing to do with being a male or female. The researchers recommend that increasing the abilities of women to participate in the labour force and generally to improve the position of women in society and generally increase the possibility to engage in entrepreneurship should be a central issue. Therefore, more targeted initiatives are also needed from parent, religious people and other stakeholders to support women's participation in entrepreneurs.

\section{Recommendations}

Based on the findings, the following recommendations are therefore provided:

(i) Creation of better information about women on labour market and women's entrepreneurship must be intensified and encouraged

(ii) Parents should be educated on their direct and indirect influence on their child's choice of entrepreneurship education and training

(iii) Religious people should also be educated on strictness to the kind of entrepreneurial skills value by their doctrines or suitable for a "child" of God

(iv) There should be a policy on gender segregation on labour market. The policy should give equal opportunities to both male and female

(v) Entrepreneurship education should be incorporated into all levels of education curriculum to ensure skills acquisition of students from childhood.

\section{References}

Aldrich, H. (1979). Organizations and Environments. Englewoods Cliffs, NJ: Prentice -Hall Inc.

Aldrich, H. (1999). Organizations Evolving. London: Sage Publications.

Becker, G. S. (1964). Human Capital. Chicago: University of Chicago Press.

Brush, C., \& Hisrich, R. D. (1999). Women-owned businesses: Why do they matter? In Z. J. Acs (Ed.), Are Small Firms Important? Their Role and Impact: 111-127. Boston, MA: Kluwer Academic Publisher.

Cerulo, K. A. (1997). Identity construction: New issues, new directions. Annual Review of Sociology, 23: 385-409.

Correll, S. J. (2001). Gender and the career choice process: the role of biased self-assessments. American Journal of Sociology, 106(6): 1691-1730.

Cotter, D. A., DeFiore, J., Hermsen, J. M., \& Marsteller Kowalewski, B. (1997). All women benifit: The macro-level effort of occupational integration on gender earnings equality. American Sociological Review, 62(5): 714-734.

Davidsson, P. (1991). "Continued Entrepreneurship: Ability,Need and Opportunity as determinats of small firm growth", Journal of Business Venturing, 6,pp 405-29.

DiMaggio, P. (1997). Culture and cognition. Annual Review of Sociology, 23: 263-287.

Driga, O; Lafuente, E; and Vaillant, Y. (2009). Gender Differences in entrepreneurial Activity: An analysis of Informal Institutional Factors. Retrieved on the $13^{\text {th }}$ July, 2011 from www.answer.com

Duchénaut, B. (1997). Women entrepreneurs in SMEs. Rennes, France: Euro PME.

Holmquist, C., \& Sundin, E. (Eds.). (2002). Företagerskan: Om kvinnor och entreprenörskap. Stockholm: SNS Förlag.

Lin, N. (1999). Social networks and status attainment. Annual Review of Sociology, 25: 467-487.

Loscocco, K. A., \& Leicht, K. T. (1993). Gender, work-family linkages, and economic success among small-business owners. Journal of Marriage and the Family, 55: 875-887.

Nnaka, C.V and Ezekannagha, G.N. (2009). Encouraging Women in Science and Technology Entrepreneurship-Issues and challenges. Science Teacher Association of Nigeria. Gender and stem education,3,pp 52-61.

OECD (2004). Women's entrepreneurship: issues and policies. OECD conference of miniters responsible for small and medium-sized enterprises. Turkey

Ridgeway, C. L. (1997). Interaction and the conservation of gender inequality: Considering employment. American Sociological Review, 62: 218-235.

Risman, B. J. (1998). Gender Vertigo. New Haven, Conn.: Yale University Press.

Smith, R. A. (2002). Race, gender, and authority in the workplace: Theory and research. Annual Review of Sociology, $28: 509-542$. Thornton, P. H. (1999). The sociology of entrepreneurship. Annual Review of Sociology, 25: 19-46.

Van-der-Lippe, T., \& van Dijk, L. (2002). Comparative research on women's employment. Annual Review of Sociology, 28: 221241 . 